\title{
Soil Arthropod Diversity and Composition Inhabited Various Habitats in Universitas Brawijaya Forest in Malang East Java Indonesia
}

\author{
Amin Setyo Leksono ${ }^{1 *}$, Ninda Merisa Putri ${ }^{1}$, Zulfaidah Penata Gama ${ }^{1}$, Bagyo Yanuwiadi ${ }^{1}$, \\ Anisa Zairina ${ }^{2}$ \\ ${ }^{1}$ Department of Biology, Faculty of Mathematics and Natural Sciences, Universitas Brawijaya, Malang 65145, \\ Indonesia \\ ${ }^{2}$ Forestry Study Program, Faculty of Forestry, Malang Institute of Agriculture, Malang 65141, Indonesia
}

Article history:

Submission August 2018

Revised August 2018

Accepted September 2018

*Corresponding author:

E-mail: amin28@ub.ac.id

\begin{abstract}
A study on soil arthropod abundance, diversity and composition have been done on November 2016 to March 2017 using pitfall traps. The objective of this study is to analyze variations of the soil arthropod abundance, diversity and composition among different habitats in a university forest. The study was carried out in Universitas Brawijaya Forest (UBF) Malang, East Java (749'S, 112 ${ }^{\circ} 34^{\prime} \mathrm{E}, 1,200 \mathrm{~m}$ in altitude), consisted of four locations: an agroforestry (AF), a gallery forest (GF), the pine stands (PS) and a settlement yard (SY). At each site, a total of 10 traps (5 by 2 rows) were placed systematically at $4-\mathrm{m}$ intervals. Glass cups $(10 \mathrm{~cm}$ in diameter and $7 \mathrm{~cm}$ deep) were buried in the ground during 24 hours. There were 2286 individuals of arthropod collected from all sampling locations. Overall the samples collected consist of 41 families of arthropods. The abundance (mean \pm $\mathrm{SE}$ ) of soil arthropod was highest in PS and the lowest in SY. Statistically, variations in abundance among locations were significant $(F=7.39, \mathrm{p}<0.01)$. The taxa richness of arthropod was highest in GF and the lowest in SY. Statistically, variations in taxa richness among locations were significant $(F=4.26, p<0.05)$. The diversity was the highest in the GF $(1.9 \pm 0.1)$ lowest in the SY $(0.74 \pm 0.1)$. Statistically, variations in diversity among study sites were significant $(F=26.73$, $p$ $<0.001)$. In general, scavenger dominated the composition of soil arthropods. The highest proportion of scavenger abundance present in SY was $84.9 \%$, while the lowest in the GF was $29.3 \%$. The highest litter transformer composition in GF was $33.9 \%$, and the lowest in SY was 8\%. The highest decomposer in PS was $26.9 \%$ and the lowest in $\mathrm{AF}$ was $12.9 \%$. The highest predator in $\mathrm{AF}$ was $20.7 \%$ and the lowest in SY was 1\%. Compositions of soil arthropod were affected by environmental factors such as soil temperature and light intensity.
\end{abstract}

Keywords: Abundance, composition, diversity, forest, soil arthropod

\section{Introduction}

Concerns about the responses of soil arthropods to the human activities such as cultivation, urbanization and silvi-culture practice have been reported in several studies [1, 2, 3, 4]. Habitat destruction and fragmentation, introduced species and deforestation are major human activities in the tropical region. These problems seem to have a serious impact on arthropod communities and diversity. East Java is located in the equatorial tropics where examples of rapid destruction of forest occurred even in mountainous areas [5, 6, 7].

There are several government programs to solve forest destruction problems particularly in association with local people development. Based on this scheme, local people involved in the management of forest based on agroforestry approach. There is evidence that cultivation of crops in agroforestry system helps to prevent uncontrolled logging and the occurrence of forest fire and sustain 
the soil arthropod diversity [8, 9]. One form of this effort is the establishment of the state forest into a university forest. The Universitas Brawijaya Forest (UBF) is a forest area who is managed by Brawijaya University in collaboration with multistakeholder including local people.

The UBF functions as a production forest, protection of life support systems, prevent a flood, maintain soil fertility and used as a living laboratory for Brawijaya University researchers. This forest is located on a slope of Mount Arjuno with an altitude of 1,200 $\mathrm{m}$ above sea level. The forest has an area of 554 ha, of which half of the area is a natural forest area, and the rest is production forest. The production area was dominated by Mahogany (Swietenia mahogany) and Pine (Pinus merkusii). One part of the production area is used for agroforestry based on coffee.

Research on soil arthropods in various types of agroforestry has been carried out. The previous research generally focuses on their role as a bioindicator or function of composition and diversity in a conservation area [10,11, 12]. Research conducted on habitat in a forest managed by the university is carried out specifically on the performance of a single species Spirobolus sp. (Diplopoda) [13]. For this reason, research is needed to identify the potential diversity of soil arthropods in various habitats at UBF as basic information for sustainable forest management. The objective of this study is to analyze variations of the soil Arthropod abundance, diversity and composition among different habitat in UBF

\section{Material and Methods}

The study was carried out in UBF Malang, East Java $\left(7^{\circ} 49^{\prime} \mathrm{S}, 112^{\circ} 34^{\prime} \mathrm{E}, 1,200\right.$ masl in altitude), consisted of four locations represent different habitats: an agroforestry (AF), a gallery forest (GF), the pine stands (PS) and a settlement yard (SY). The characteristic among study sites was presented in Table 1.

Soil Arthropods were collected ones a month during November 2016 to March 2017 using pitfall traps. At each site, a total of 10 traps ( 5 by 2 rows) were placed systematically at 4-m intervals [14]. Glass cups $(10 \mathrm{~cm}$ in diameter and $7 \mathrm{~cm}$ deep) were buried in the ground. The traps were filled with $100 \mathrm{~mL}$ alcohol solution (70\%) mixed with a few drops of detergent. The insects collected from each sampling unit were sorted and identified in families based on several identification books [15, 16, 17]. Identification of was carried out by observing their characteristics, which were then matched using key identification according to identification books. The identification was done to the taxonomic level of the family in Laboratory of Animal Diversity, The Faculty of Mathematics and Natural Sciences, Brawijaya University, Malang, Indonesia. Environmental factors (light intensity, soil temperature, and soil humidity) were measured three times in each plot every sampling. Ground cover plant diversity and litter thickness were measured ones, adjacent to each sampling plot.

The differences in the soil arthropod abundance and diversity were analyzed by using analysis of variances (ANOVAs). The tests were performed using SPSS ${ }^{\circledR}$ version 16 (SPSS Inc. Chicago, IL, USA), and the F-statistic test was considered significant when $\mathrm{p} \leq 0.05$. Canonical correspondence analysis (CCA) was applied to analyze the relationship between the abundance of families and environmental variables (ground cover plant diversity, litter thickness, soil temperature, soil humidity, and light intensity) using the PAST ver. 2.17c. All factors were coded as categorical variables. Only ten common families were included in the analysis because of sample size. The soil arthropod compositions in all locations were compared with the Bray-Curtis similarity index followed by K-means clustering.

\section{Results and Discussion}

There were 2286 individuals of Arthropod observed visually in the study sites. Overall the samples showed that rice plants were visited by 41 families of Arthropods. Overall, Formicidae, Grillydae, Isotomidae, Armadilidae and Staphylinidae were dominant in the traps composing about 93.4\% individual $(29.4 \%$ in AF, $22.1 \%$ in GF, in $36.1 \%$ PS and $12.4 \%$ in SY). These families tend to have various habitat distributions. Formicidae, Armadilidae, Cleridae and Miscellanies were more abundant in AF, Theridiidae was more abundant in GF. Grillydae, Isotomidae, Staphylinidae, Scarabaeidae, Thiphiidae were more abundant in PS (Table 2).

The abundance, taxa richness and diversity of soil arthropod varied between locations. This study showed that of the abundance (mean \pm SE) of arthropod was highest in PS (206.25 \pm 28.36$)$, 
Table 1. Habitat characteristic among study sites Agro-Forestry (AF), Gallery Forest (GF), Pine Stands (PS), and Settlement Yard (SY)

\begin{tabular}{ccccc}
\hline Characteristics & AF & GF & PS & SY \\
\hline Main tree & Pine and coffee tress & Mahogany & Pine trees & None \\
Litter thickness $(\mathrm{cm})$ & 5.7 & 1.1 & 4.2 & 0.7 \\
Ground cover vegeta- & Asteraceae, & Juglandaceae and & Asteraceae and & Poaceae \\
tion & $\begin{array}{c}\text { Poaceae, Rosaceae, } \\
\text { Polygonaceae }\end{array}$ & Urticaceae & Poaceae & \\
Ground cover density & Few grass and & High shrubs and & Few grass and & Few grass \\
& herbaceous plant & very dense & herbaceous plant & Very high \\
Human activities & High & Very low & Low & Ver
\end{tabular}

Table 2. Abundance (mean \pm SE) of soil Arthropod among habitats

\begin{tabular}{ccllll}
\hline No. & Groups & \multicolumn{1}{c}{ Agro-forestry } & \multicolumn{1}{c}{ Gallery forest } & Pine stands & Settlement yard \\
\hline 1. & Formicidae & $57.50 \pm 11.51$ & $30.25 \pm 4.77$ & $52.75 \pm 22.84$ & $53.50 \pm 25.05$ \\
2. & Grillydae & $24.50 \pm 5.80$ & $38.50 \pm 6.99$ & $44.75 \pm 3.07$ & $4.25 \pm 2.46$ \\
3. & Isotomidae & $4.50 \pm 2.90$ & $19.50 \pm 2.87$ & $30.75 \pm 18.36$ & $0.00 \pm 0.00$ \\
4. & Armadilidae & $26.50 \pm 10.43$ & $5.50 \pm 1.19$ & $13.75 \pm 6.33$ & $0.00 \pm 0.00$ \\
5. & Staphylinidae & $12.25 \pm 3.77$ & $10.25 \pm 1.11$ & $18.25 \pm 8.15$ & $0.25 \pm 0.25$ \\
6. & Scarabaeidae & $13.0 \pm 6.490$ & $5.25 \pm 1.70$ & $21.25 \pm 6.10$ & $0.00 \pm 0.00$ \\
7. & Theridiidae & $4.25 \pm 1.75$ & $6.50 \pm 0.65$ & $4.25 \pm 1.89$ & $0.00 \pm 0.00$ \\
8. & Cleridae & $11.50 \pm 11.50$ & $0.00 \pm 0.00$ & $0.25 \pm 0.25$ & $0.00 \pm 0.00$ \\
9. & Thiphiidae & $0.00 \pm 0.00$ & $0.00 \pm 0.00$ & $10.50 \pm 10.50$ & $0.00 \pm 0.00$ \\
10. & Japygidae & $0.00 \pm 0.00$ & $0.00 \pm 0.00$ & $0.00 \pm 0.00$ & $9.25 \pm 6.50$ \\
11. & Miscellanies & $14.00 \pm 3.24$ & $10.50 \pm 3.66$ & $9.75 \pm 1.03$ & $3.75 \pm 1.75$ \\
\hline
\end{tabular}

and the lowest in SY $(71.00 \pm 24.75)$. Statistically, variations in abundance at these various locations were significant $(F=7.39, p<0.01)$. Post hoc test showed that the soil arthropod abundance in AF and PS was significantly higher than that in SY. That in GF was lower than those in AF and PS but statistically not significant (Figure 1).

The taxa richness Arthropod was highest in GF (12.5 \pm 1$)$, and the lowest in SY (6.25 \pm 1.49$)$. Statistically, variations in taxa richness among study sites were significant $(\mathrm{F}=4.26, \mathrm{p}<0.05$. Post hoc test showed that taxa richness in AF and GF were significantly higher than that in SY. That in PS was lower than those in AF and GF but statistically not significant (Figure 2).

The diversity was highest in GF $(1.9 \pm 0.1)$ lowest in SY $(0.74 \pm 0.1)$. Statistically, variations in diversity among locations were significant $(\mathrm{F}=$ 26.73, $\mathrm{p}<0.001$ ). Post hoc test showed that soil arthropod diversities in AF, GF, and PS were sig- nificantly higher than that in SY (Figure 3).

In general scavenger dominated the composition of soil Arthropods. The highest proportion of Scavenger abundance at SY was $84.9 \%$, while the lowest in the GF was $29.3 \%$. The highest litter transformer composition in GF is 33.9\%, and the lowest in SY is 8\%. The highest decomposer at PS is $26.9 \%$ and the lowest in $\mathrm{AF}$ is $12.9 \%$. The highest predator in AF is $20.7 \%$ and the lowest in SY is $1 \%$ (Figure 4 ).

The result of the K-means cluster analysis showed that soil Arthropod assemblage according to the degree of human activities. The family similarity was greater between the soil Arthropod composition in GF and PS (72\%). Branching of these compositions with that in Agroforestry was occurred at $65 \%$, while those compositions with that in Settlement yard occurred at $40.7 \%$ (Figure 5).

The highest litter thickness was in AF and the 


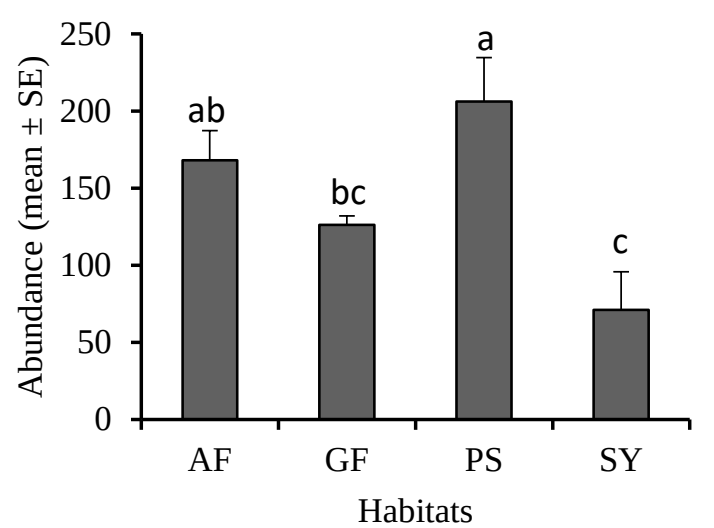

Figure 1. Variation of the soil Arthropod abundance among different habitats in AF (Agro-Forest), GF (Gallery Forest), PS (Pine Stands), SY (Settlement Yard)

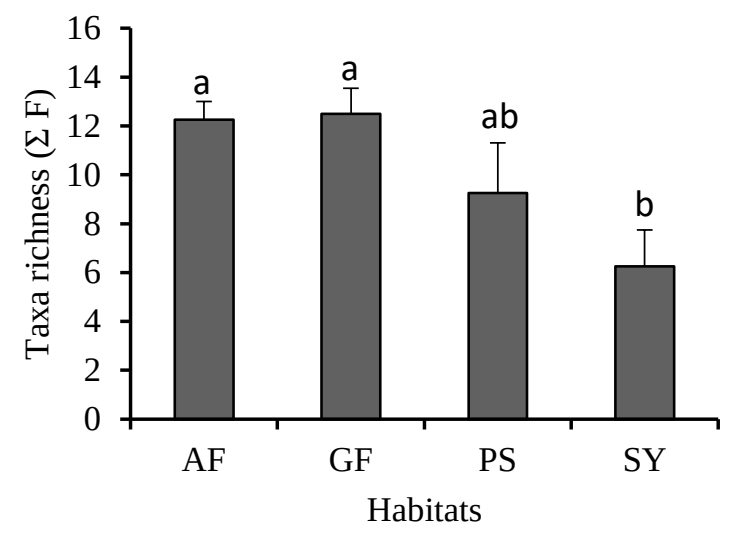

Figure 2. Variation of soil Arthropod taxa richness among different habitats in AF (Agro-Forest), GF (Gallery Forest), PS (Pine Stands), SY (Settlement Yard)

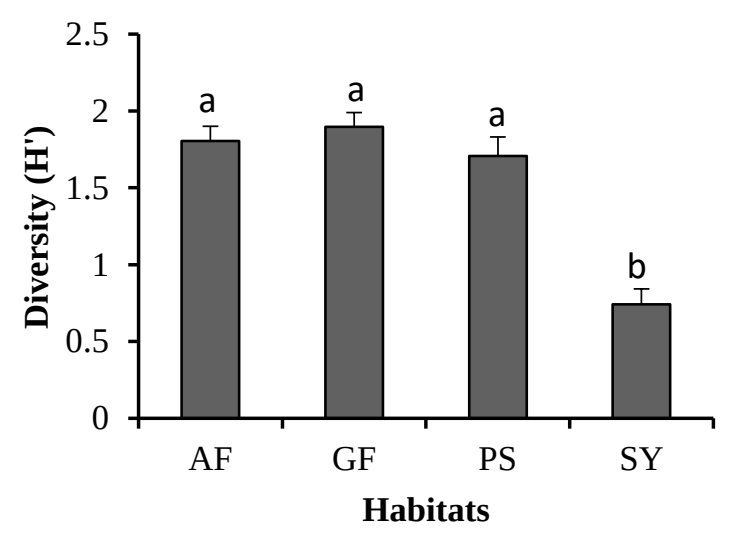

Figure 3. Variation of the soil Arthropod diversity among different habitats in AF (Agro-Forest), GF (Gallery Forest), PS (Pine Stands), SY (Settlement Yard) lowest is in SY. Ground cover diversity and soil humidity were highest in GF and lowest in PS. Light intensity and soil temperature were highest in SY and lowest in GF (Figure 7).

The highest abundance of soil arthropod occurred in pine stands, where the most dominant family live whereas, the taxa richness and diversity were higher in GF and AF. In the GF area, diversity and plant species of angiosperms are higher than the others. Biotic factors affect the abundance of food sources, while abiotic factors influence the development and act as a limiting factor in the life of an organism [18].

From the results of this study it can be seen that Formicidae and Gryllidae strongly dominating the samples. The Gryllidae as herbivorous insects utilize a wide range of their food source including the group of angiosperm plants. Formicidae was more abundant in AF and in the PS because it living in under leave or in the fruit bunches of coffee as well as live in pine nuts [19]. The abundance of food is a factor that influences the formation of colonies from the Formicidae because the food is a major requirement for the ants. The high abundance of the Gryllidae family is due to the suitability of the habitat for the crickets. This family is nocturnal insects. During the daylight the crickets hid in their burrow home, behind under the rocks or tree debris. In the gallery forest area, a seasonal watershed with lots of rocks and tree debris was available making it profitable for Gryllidae. This behavior is common among arthropod group such as: ants, wasps, bees, and crickets [20, 21]. Many species of the cricket, burrows by themselves, or use naturally occurring gaps and slots as shelter [22]. Burrows are used as a shelter from predators like birds or lizards, but also for seasonal mating and oviposition [23, 24].

The main reason for the dramatic decline in population in crickets is usually related to habitat size, or the influence of agricultural intensification. A field of cricket lives in dry, oligotrophic habitats, like heath land and dry grassland. One of the factors changing the microclimate and food sources can be grazing of animals like horses, cattle and sheep [25]. In general scavenger dominates the composition of soil arthropods. The highest proportion of Scavenger abundance at settlement yards was $84.9 \%$, while the lowest in the gallery forest was $29.3 \%$. In the location of settlement yards, which is close to the settlement, the high 


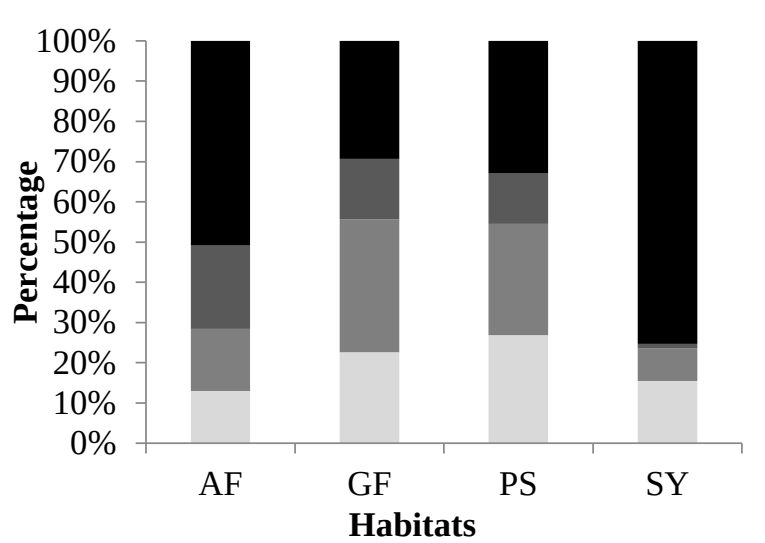

- Scavenger - Litter transformer

Predator

Decomposer

Figure 4. Soil arthropod functional group compositions among different habitats

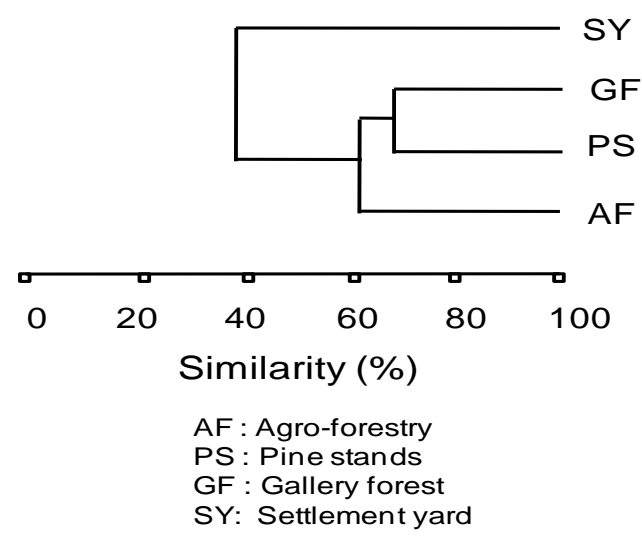

Figure 5. Dendrogram showing similarity among compositions of Soil Arthropod among different habitats

proportion of scavenger is related to the abundance of Formicidae. Formicidae is commonly found in habitats with a high level of human activity. Meanwhile, the lowest abundant present in a relatively more natural habitat because in the habitat the composition of the functional status is relatively balanced. The balance of this composition will affect the balance of the ecosystem. Formicidae is known as one of the arthropods that have a high level of resistance to environmental changes. Its habitat also overlaps with human settlement [26]. Naturally, Formicidae could be used as the indicator of agroecosystem [27] as well as indicators for environmental changes, mainly for habitat disturbance and destruction i.e. forest clearing [28], forest fires, disturbance to vegetation, deforestation, mining, waste disposal and land use fac- tor [29]. Generally, highly disturbed areas have fewer species, and the number of ants better than moderated or lightly disturbed areas. The communities in disturbed areas were even dominated by a single species such as Dorymyrmex smithi [30].

In general, scavenger and decomposer dominate samples from all four locations. This indicates that in the three study areas there is a high level of organic degradation activity that helps soil fertility. The proportion of Predators is highest in $\mathrm{AF}$, this is quite positive because agroforestry is susceptible to attack by pests. High predator abundance plays an important role in pest control. As for the lowest proportion of predators occurring at the settlement yard, this indicates an ecosystem imbalance which is characterized by the domination of single functional group. The low proportion of predator in settlement yard also affects the pest control which generally arose from the herbivore group. The existence of herbivorous insects for agriculture such as agroforestry with large populations will cause damage to plants. The predatory insects are natural enemies of herbivorous insects that play a role in controlling the insectivorous herbivorous population so as to create stability of food webs in an ecosystem.

In a grouping pattern of the arthropod composition appeared that most families showed consistent abundance in some habitats. This means that the family group is able to adapt to a variety of habitats. However, some families tend to prefer more natural habitats, others prefer more modified habitats. Temperature and light intensity are very influential on soil arthropod composition. Surprisingly, the existence of ground cover plant and litter thickness has little effect on the composition. This situation showed that the litter thickness as a food source and habitat for soil arthropod but not the only important factor that determines the abundance of arthropod soil. Each habitat has a different combination of environmental factors. Each combination of factors has a different influence on the type or group of soil arthropod, both beneficial and detrimental. Geographical regions that have different patterns of climate, vegetation, and other factors are inhabited by a different group and with different diversity composition. Habitat preference also depends on the absence of their predators and competitors. Other research showed that the microarthropod abundance along the land use 


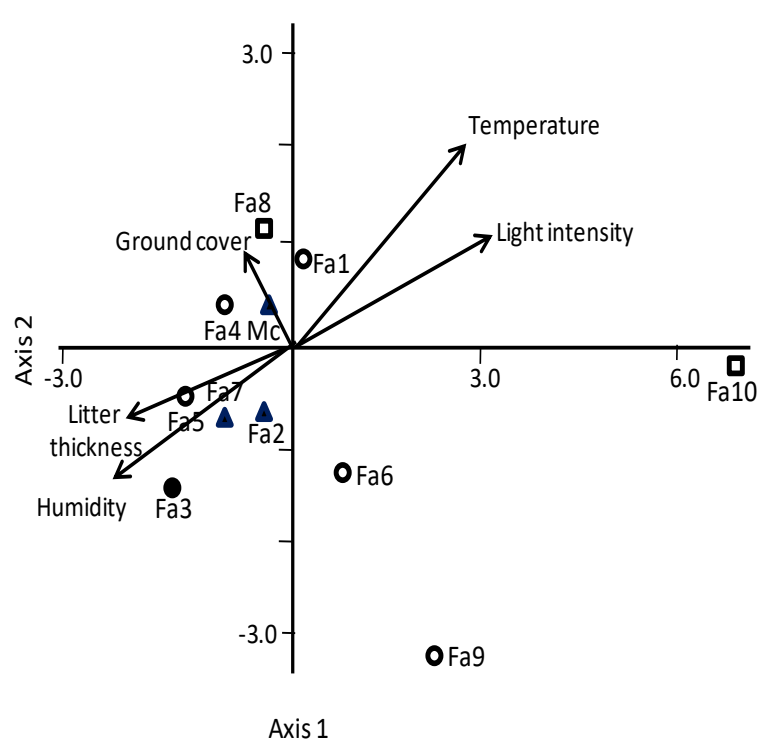

Figure 6. Family composition of soil Arthropod responding to environment factors: arrows represent the degree of an environmental variable. The code of families attached was grouped by UPGMA k-means clustering represent by the same shape. Numbers in the family score are as follows: Fa1. Formicidae, Fa2. Grillydae, Fa3. Isotomidae, Fa4. Armadilidae, Fa5. Staphylinidae, Fa6. Scarabaeidae, Fa7. Theridiidae, Fa8. Cleridae, Fa9. Thiphiidae, Fa10. Japygidae Fa11. Miscellanies

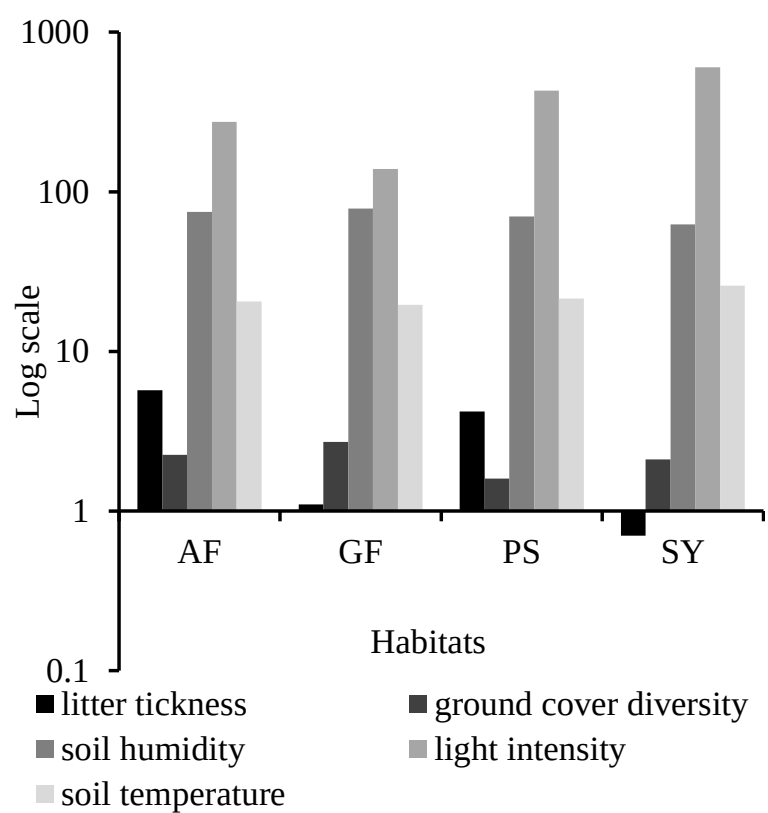

Figure 7. Variations in environmental factors among different habitats in AF (Agro-Forest), GF (Gallery Forest), PS (Pine Stands), SY (Settlement Yard) gradient was not correlated with decreasing temperature or increasing or C-to-N ratio [31]. This is also supported by other study showing that besides physical factors such as litter depth, soil chemical properties such as total carbon, sodium and calcium also affect soil arthropod abundance [32].

Abiotic factors including soil temperature and light intensity were among the of soil physical factors that determine the existence and density of soil organisms. Variations in temperature and light intensity showed a negative relationship with soil abundance of arthropods. It seems that soil arthropod tends to avoid habitats that have the high light intensity and soil temperature. Soil arthropods generally prefer moist and shade habitats. This was supported by many studies such as reported that trees shaded affected the number of species [3]. Species richness is highest in habitat with two strata of shade canopy trees, hence inhibit of light penetration. Other research suggested that precipitation and temperature were significantly correlated with Collembola and Mesostigmata densities and also with total arthropod [33].

\section{Conclusion}

This study showed that the abundance (mean \pm SE) of soil arthropod was highest in PS and the lowest in SY. The taxa richness and diversity of soil arthropod was highest in GF and the lowest in SY. In general scavenger dominated the composition of soil arthropods. The highest proportion of scavenger abundance present in SY, while the lowest in the GF. Formicidae, Grillydae, Isotomidae, Armadilidae and Staphylinidae were dominant in the traps composing about $93.4 \%$ individual. Compositions of soil arthropod were affected by environmental factors such as soil temperature and light intensity.

\section{Acknowledgment}

The author thanks to Rector of Universitas Brawijaya, Director of UBF, and Dr. M. Sasmito Djati (Vice Rector IV UB) for facilitating and funding this research.

\section{References}

1. Stamps WT, Erik A, Nelson EA, Linit MJ, (2009) Survey of diversity and abundance of ground-dwelling arthropods in a black walnut-forage alley-cropped system in the mid-western united states. Journal of the Kansas Entomological Society 82 (1): 46 - 62. doi: 10.2317/JKES705.01.1 
2. Schowalter TD, Zhang YL, Rykken JJ (2010) Litter invertebrate responses to variable density thinning in Western Washington. Forest Ecological Applications 13:1204-1211. doi: 10.1890/02 5187.

3. Toana MH, Mudjiono G, Karindah S, Abadi AL (2014) Diversity of arthropods on cocoa plantation in three strata of shade tree Agrivita 36 (2): 120 - 127. doi doi.org/10.17503/agrivita.v36i2.395.

4. Rohyani IS, Ahmadi H (2017) Short communication: Diversity and abundance of soil insects at jeruk manis protected forest in East Lombok (Indonesia) using several trapping methods. Biodiversitas 18 (2): 809 - 812. doi.10.13057/biodiv/d180253

5. Dallmeier F, Comiskey JA (1998) Forest biodiversity research, monitoring and modelling: Conceptual background and old world case studies. Paris; New York, Parthenon Publishing.

6. Leksono AS, Nakagoshi N, Isagi Y (2005) The effect of forest disturbance on flying insect assemblages in Trawas, East Java. Tropics 14 (4): 335 - 343. doi: 10.3759/tropics.14.335.

7. Partel M, Chiarucci A, Chytry M, Pillar VD (2017) Mapping plant community ecology. Journal of Vegetation Science 28 (1): 1 - 3. doi: $10.1111 /$ jvs.12490.

8. Santoso E, Sugiyama N, Hikosaka S, Kawabata S (2003) Cultivation of Amorphophallus muelleri blume in timber forests of East Java, Indonesia. Japanese Journal of Tropical Agriculture 47: 190 - 197. doi: 10.11248/jsta1957.47.190

9. Leksono AS, Yanuwiadi B, Kusuma Z et al. (2011) Influence of porang (Amorphophalus muelleri) cultivation on the composition of soil arthropods in tropical agroforestry areas in East Java, Indonesia. Journal of Tropical Life Science 1 (2): 76 - 81. doi: 10.11594/jtls.01.02.05.

10. Santorufo L, Van Gestel CAM, Rocco A, Maisto G (2012) Soil invertebrates as bioindicators of urban soil quality. Environmental Pollution 161: 57 - 63. doi: 10.1016/j.envpol.2011.09.042.

11. Suheriyanto D, Soemarno, Yanuwiadi B, Leksono AS (2016) Soil arthropods diversity on the forest floor and ex-road in Manggis Gadungan Kediri Regency. Indonesia Jurnal Teknologi 78 (5): 399 - 403. doi.org/10.11113/jt.v78.8344.

12. Zayadi H, Hakim L, Leksono AS (2013) Composition and diversity of soil arthropods of Rajegwesi Meru Betiri National Park. Journal of Tropical Life Science 3 (3): 166 - 171. doi: 10.11594/jtls.03.03.04.

13. Musyafa (2005) The roles of soil macrofauna on litter decomposition of Acacia mangium Wild. Biodiversitas 6 (1): 63 - 65 doi:10.13057/biodiv/d060113.

14. Sota T, Nakano S, Hasan N et al. (2001) Fluctuation in the abundance of terresterial arthropods at an arable field in west sumatran highland. Tropics 10 (3): 463 - 472. Doi: 10.3759/tropics.10.463

15. Lilies SC (1992) Key determination of insects. Jakarta, Kanisius.
16. Johnson NF, Triplehorn CA (1989) Borror and Delong's introduction to the study of insects 7th Edition. Boston, Brooks Cole.

17. Suin NM (1997) Ecology of soil fauna. Jakarta, Bumi Aksara.

18. Price PW, Denno RF, Eubanks MD et al. (2011) Insect ecology: Behavior, populations and communities. Cambridge, Cambridge University Press.

19. Syaufina L, Haneda NF. Buliyansih A (2007) Keanekaragaman arthropoda tanah di hutan pendidikan gunung walat. Media Konservasi 12 (2): 57 - 66 .

20. Holzer B, Jacot A, Brinkof MWG (2003) Condition-dependent signaling affects male sexual attractiveness in field crickets, Gryllus campestris. Behavioral Ecology 14 (3): 353 - 359. doi: 10.1093/beheco/14.3.353.

21. Ritz MS, Kochler G (2007) Male behaviour over the season in a wild population of the field cricket Gryllus campestris L. Ecological Entomology 32 (4): 384 - 392. doi: 10.1111/j.13652311.2007.00887.x.

22. Endo C (2008) An analysis of the horizontal burrow morphology of the oriental mole cricket (Gryllotalpa orientalis) and the distribution pattern of surface vegetation. Canadian Journal of Zoology 86 (11): 1299-1306. doi.org/10.1139/Z08-116.

23. Rodriguez-Muñoz R, Bretman A, Walling C et al. (2010) Natural and sexual selection in a wild insect population. Science 328 (5983): 1269 - 1272. doi: 10.1126/science.1188102.

24. Bretman A, Rodriguez-Muñoz R, Walling C et al. (2011) Finescale population structure, inbreeding risk and avoidance in a wild insect population. Molecular Ecology 20 (14): 3045 3055. doi: 10.1111/j.1365294X.2011.05140.x.

25. Rada S, Mazalová M, Šipoš J, Kuras T (2014) Impacts of moving, grazing and edge effect on orthoptera of submontane grasslands: Perspectives for biodiversity protection. Polish Journal of Ecology 62 (1): 123 - 138. doi: 10.3161/104.062.0112.

26. Wilkie KTR, Mertl AL, Traniello JFA (2010) Species diversity and distribution patterns of the ants of Amazonian Ecuador. Plos One 5 (10): 1 - 12. doi: 10.1371/annotation/832d6104-4f9f42eb-88a5-b2b1fc4480ca.

27. Peck SL, McQuaid B, Campbell CL (1998) Using ant species (Hymenoptera: Formicidae) as a biological indicator of agroecosystem condition. Environmental Entomology 27 (5): 1102 1110. doi: 10.1093/ee/27.5.1102.

28. Nakamura A, Catterall CP, House APN (2007) The use of ants and other soil and litter arthropods as bio-indicators of the impacts of rainforest clearing and subsequent land use. Journal of Insect Conservation 11 (2): 177 - 186. doi: 10.1007/s10841006-9034-9.

29. Wang C, Strazanac J, Butler L (2000) Abundance, diversity, and activity of ants (Hymenoptera: Formicidae) in oak-dominated mixed Appalachian forest treated with microbial pesticides. Environmental Entomology 29 (3): 579 - 586. doi: 10.1603/0046225X-29.3.579. 
30. Graham JH, Krzysik AJ, Kovacic DA et al. (2009) Species richness, equitability, and abundance of ants in disturbed landscapes. Ecological Indicators 9 (5): 866 - 877. doi: 10.1016/j.ecolind.2008.10.003.

31. Migge-Kleian S, Woltmann L, Anas I et al. (2007) Impact of forest disturbance and land use change on soil and litter arthropod assemblages in tropical rainforest margins. In: Tscharntke $\mathrm{T}$, Leuschner C, Zeller M et al. (Eds.) Stability of tropical rainforest margins. environmental science and engineering (Environmental Science). Berlin, Heidelberg, Springer.
32. Palacios-Vargas J, Castaño-Meneses G, Gómez-Anaya JA et al. (2007) Litter and soil arthropods diversity and density in a tropical dry forest ecosystem in Western Mexico. Biodiversity and Conservation 16 (13): 3703 - 3717. doi: 10.1007/s10531-0069109-7

33. Ashford O, Foster WA, Turner BL et al. (2013) Litter manipulation and the soil arthropod community in a lowland tropical rainforest. Soil Biology and Biochemistry 62: 5 - 12. doi: 10.1016/j.soilbio.2013.03.001. 